\title{
Artistic Reflections: The Use of Photo Elicitation Method Toward Visual Artists
}

\author{
Andry Prasetyo \\ Department of Photography, Faculty of Art and Design, \\ Indonesian Institute of Arts Surakarta, Indonesia
}

\begin{abstract}
By this research, the author conducted the detailed and reflected of the process of photo-elicitation as a step to access respondents and to figure out theirs voices of selected word and visual. The subject of this research is a photographer from Solo, Central Java, named Pandji Vasco Da Gama. With his serial photos, titled "Republik Kresek". The author described in detail using a photo-elicitation interview upon Pandji's experiences with the qualitative method. First, the research conducted the identification and detailed about photo elicitations, literature study, and empirical experiences of the author for the discussion. Second, explain with related methodology about the findings during the research process. At the end of this research, the author described in a reflective way their voice related with empirical photographer's experiences thought, and also creativity attraction as a result of the photo-elicitation interview. The conclusion of this research said that there is a potential finding during visual methodology, which is the photo is the metaphor of the meaning, photo as a representation of meaning that was attached and participant's empowerment.
\end{abstract}

Keywords: Photo-elicitation method, artistic reflection, participant's empowerment

DOI: $10.7176 / \mathrm{ADS} / 98-02$

Publication date: January $31^{\text {st }} 2022$

\section{Introduction}

1.1 Photo-elicitation interviewing

The photo-elicitation interviewing method becomes a way to support the researcher when eager to know about events or momentum that is impossible to see directly (Richard and Lahman, 2015a). As Patton (2015) the moment is when the researcher wants to know about respondents, like the painter's movement, what they are thinking, and how they feel when focusing the lens toward an object, the intention of respondents. Adding the photos during the interview would help a researcher to get additional information, especially mind dimension, feelings, experiences, and understanding of unseen objects (Patton 2015: 70). Through this research, we want to reveal the use of the photo-elicitation interview practical method toward photographer Pandji Vasco Da Gama.

Based on the development of the social study, at the end of 19 century, visual research is commonly used in social study; such as in building relationships (Richard et al., 2014); (Collier et al., 1986); (Richard and Lahman, 2015a), giving access for respondent lives (Clark-Ibanez and Stanczak, 2007), to give togetherness experiences and describes stagnant information and reduces ineffective questions (Harrist, 2014); (Leonard and McKnight, 2015); (Richard et al., 2014). The photo-elicitation interview method gives an alternative way for the researcher, in some cases, who could not able to observe directly toward the subject or event. It could be caused by the event being already finished or it was too fast for the researcher to see or observe. As Michael Quinn said, that limitation obstructed the researcher to drag the audience's attention to feelings, opinions, respondent's desires, or previous behavior (Quinn, 2002). Based on (Olien, 1968), the visual research method is commonly used in sociology or ethnography studies. Research using picture or photos are easier to memorize (Creswell, 2012). Intrinsicly, pictures contain data. It could be said that picture also should be treated as data sources, which is collected systematically, analyzing and presented in good methodology. Furthermore, visual research in art and cultural study also uses pictures or photos as instruments. As we know, the imagination of photos comes first before the explanation. Like Berger said in Prasetyo, "Seeing comes before words. The child looks and recognizes before it can speak" (Prasetyo, 2019). On the other hand, Gillian Rose divides visual research becomes three sides, they are the site of the production of an image, the site of the image itself, and the site where it is seen by various audiences (Rose, 2001)

The method of the photo-elicitation interview could be defined as an interviewing technique in which researchers elicit information from participants by using photographs (Richard et al., 2014); (Series and Jun, 2015); (prosser, 2005). The information and reveal the meaning beyond photos It could be digging up the other aspects including expression from the respondents. It is clearly different from the common interview technique. In this technique, sometimes it's just used notes and words only. Interview using photos, an interviewer could stimulate the memory and experiences of participants compare using words. Collier said, photo-elicitation open opportunity to obtain information that is not only from respondents to the researcher but from both sides. "We were asking questions of the photographs and the informants became our assistants in discovering the answers to these questions in the realities of the photographs, We were exploring the photographs together" (Collier et al., 
1986). Banks confirmed that, in the photo-elicitation technique, there is some main utility, such as (1) to reveal respondent's cultural background, (2) to find out the psychology aspect, (3), to examine the thought and understanding ability (Suchar, 1989). Bank emphasized that the photo-elicitation process pointed out the memory, makes the interview more focused, as an "ice-breaker" the awkward situation, and helps participants to get the forgotten things back (Banks, 1998).

\section{Literature Review}

It seems that visual research is not able to put aside the photo-elicitation in getting data in the interview process while also doing the field observation. Besides that, researchers from different studies also use photo-elicitation to do the research, such as education programs, art, psychology, organizational study and etc. One of literature as a reference is "Visual Anthropology: Photography as a Research Method", written by Dr. Collier. This book discusses the extention of photo function as a new approach in etnography research. Dr.Collier showed how photo could be used to stimulate the new ideas of investigation.

Based on his experience, photography could be used as stimulation for new ideas of using photos to start the action (Collier et al., 1986). Elicitation study of Douglas Harper's photos discussed first the definition and the history of elicitation in perspective anthropology and sociology. Elicitation understanding, based on two disciplines, was conducted by considering the topic and shape. Elicitation photo's history was discussed in detail, starting from all disciplines that are used. In conclusion, photo-elicitation is able to enlarge the opportunity for empirical research. Besides that, this study also said that photo-elicitation is able to produce different information that reveals information, feelings, and memory from photos (Harper, 1986).

Dona Schwartz wrote photography as authentic evidence and specifically, the photo's context shows the people attributes, objects, situations, and undescribed phenomenon. Dona reveals the truth of the photo through the photo manipulation case in Minneapolis Star Tribune, December 31st, 1996. In that case, Greener, the photographer, got sanctioned two days off because of erasing the cable and making the photo different from the fact. His reason did that was just for the beauty of the photo (Schwartz, 1999). The importance of elicitation in order to reveal information is written by Marcus Bank. They are three basic theoretical understandings of using photos in visual research: how information systems in photos could be gathered, analyzed, and presented. For developing research capacity, it was suggested to attach the photo to help get data especially when the photo becomes the main feature of the information system (Banks and Zeitlyn, 2015).

Marcus Bank, in historical perception, wrote that photos that were used in an interview have an important role for participants. Therefore, their's interpretation could be discussed. There are two photo variants that could be used to get the data research. First, the photo was produced during the research process and related to the topic, archive photo that was taken before the research and not related to the topic. Second, a photo that was taken by the participants, including the requested photo from the Meanwhile, the use of photos in the interview process is written by Charles Suchar. He decided into three functions: (1) reveal the participant's cultural background, (2), reveal social and psychological aspects, (3) evaluate participants' understanding of their thought and action in social situations (Suchar, 1989). The collaboration model, between participants and researcher, was written by Douglas Harper. By the collaboration, the interview could be as a dialog that stimulated by photo (Harper, 1986).

Photo elicitation, as postmodern dialog, prefer subject authority rather than researcher, it is written by Maria Lahman. Her reason is based on the development of the photo-elicitation method, an interview process dominated by the informant. Then, the researcher prefers to follow the information from the participants. This method is more authentic because the idea directly comes from the information source (Richard and Lahman, 2015b).

In early research about photo-elicitation, the methodology was used to know how the elicitation method is used in gathering visual research data. Photo is used as an intermediary between the researcher and the subject to get empirical information and experiences. This research also explains the benefit of using a photo-elicitation method and invites the visual researcher to use this method considering photos in the past moment were only just as documentation in the field. The researcher also concludes that the photo-elicitation method is helpful in gathering data, in textual and contextual. Photo, as a metaphor meaning, encourage psychological data and reveals empirical data in cultural understanding. With the photo-elicitation method, a researcher is able to get more data, either in its type or quality (Prasetyo, 2020).

This article explains about experiences of interview using photo elicitaion method that conducted by the researcher. Tha subejct of researcher is visual artist (photographer) from Solo City, Panji Vasco Da Gama. Photo that were used in photo-elicitation interview consist of 20 photos. Thoses serial photo is titled "Republik Kresek". Three of 20 photos were chosen by the respondents and represented fiction story of disappointment, sadness, caring, hope and also terror of plastics garbage pollution. In interview methodology of photo-elicitation, this research would conduct in some steps, such as: 


\section{Method}

3.1 Select Respondent

Respondents should be selected considering the research topic and researcher's capability. In this interview, the respondent is Pandji Vasco Da Gama, an visual photographer in Solo. The first step should be conducted in interview is preparing interview action, taking some notes which includes behaviour table. This step is helping the interviewer not to take some notes during interview. The researcher just takes check-marks on the list for some detailed. Then, voice recorder is also important to prepare.

Table 1. Respondent Behaviour: Verbal dan Non-verbal. Source: (Sarwo, 2016).

\begin{tabular}{|c|c|c|}
\hline No & Behaviour types & Category \\
\hline 1. & Verbal & $\begin{array}{ll}\text { - } & \text { Willing to talk } \\
\text { - } & \text { Speak fluently } \\
\text { - } & \text { Talkative } \\
\text { - } & \text { Normal talk } \\
\text { - } & \text { Normal normal and sometimes louder }\end{array}$ \\
\hline 2. & Smile & $\begin{array}{ll}\text { - } & \text { Grin } \\
\text { - } & \text { Spontaneous } \\
\text { - } & \text { Sincere } \\
\text { - } & \text { Punctual } \\
\end{array}$ \\
\hline 3. & Eye contact & $\begin{array}{ll}\text { - } & \text { Eye contact } \\
\text { - } & \text { Sometimes } \\
\end{array}$ \\
\hline 4. & Face expression & $\begin{array}{ll}\text { - } & \text { Bright } \\
\text { - } & \text { Relax } \\
\text { - } & \text { Happy } \\
\text { - } & \text { Cheerful } \\
\end{array}$ \\
\hline 5. & Gesture & - Hand and body gesture \\
\hline 6. & Sitting position & $\begin{array}{ll}\text { - } & \text { Relax } \\
\text { - } & \text { Familiar } \\
\text { - } & \text { Polite } \\
\end{array}$ \\
\hline 7. & Nod & - $\quad$ Nod approval \\
\hline 8. & palms & $\begin{array}{ll}\text { - } & \text { Warm hand } \\
\text { - } & \text { Normal } \\
\end{array}$ \\
\hline 9. & hair & $\begin{array}{ll}- & \text { Neat } \\
\text { - } & \text { Orderly }\end{array}$ \\
\hline 10. & cry & - $\quad$ Not cry \\
\hline 11. & clothes & $\begin{array}{ll}\text { - } & \text { Clean } \\
\text { - } & \text { Tidy } \\
\end{array}$ \\
\hline
\end{tabular}

3.2 Time and Place

Discuss the time and location for the interview with the respondent. Before doing this, the interviewer makes informal conversation to build closeness with the respondents. After that, the interviewer explains the goal of the research with a clear description. It is to avoid misinterpretation from the respondent toward the research process. After the respondent acknowledged the steps and goal, the interviewer proposed a coffee shop as the place to conduct the interview. The coffee shop is chosen because both interviewer and respondents are fond of coffee.

\subsection{Attitude}

During an interview, both interviewer and respondent get and give respect for their answer. Both avoided criticizing the answer but tried to pay attention, giving an opportunity to explore the experiences.

\subsection{Select Photos}

Most of the photos were taken in Solo dan Jakarta in 2019. The photo models were not professional models but ordinary people who volunteered to be taken in photo locations. Some of the models were dance artists, plasticrecycled businesses person, students, farmers, and housewives.

There are 20 photos that were printed in black and white glossy, describing the human cycle from birth, growing up until death. The important message in the photos is every model used a plastic bag in their head for each activity. Emphasizing the sense of sentiment, melodramatic, even naive, along with the exhibition which was held in Leica Playground, Plaza Senayan, Jakarta. The photos represented the dream of urban people in a 
caring environment. As is said before, photos in this research were selected by the respondent who is also a photographer. In the matter of this research, the researcher gave the message for the respondent to choose a photo that reflects his idea about "Republik Kresek". So, there are three selected photos that describe a human's cycle in life: birth, growing up, and death. (Figure 3,4 and 5).

\subsection{Creating Conversation}

To achieve the goal of a photo-elicitation interview needs some conditions. Photo elicitation as a technique for getting information put the respondent not feel like interrogative situations, but it induces the creative and critical opinion toward the photos. The respondent could freely give their opinion and feelings. As a reminder, during an interview, the interviewer has an equal position to the respondent. An interviewer needs to be patient and not control too much of the conversation. So, an interview will be done freely and smoothly with face-to-face conversation. It could be, during the interview, respondents will feel dictated. When it happens, the interviewer will see in their reaction, such as stop talking, low voice, facial expression, make a frown face, and changing the sit position or refused eye contacts and look not so excited.

The process of research could be described systematically below:

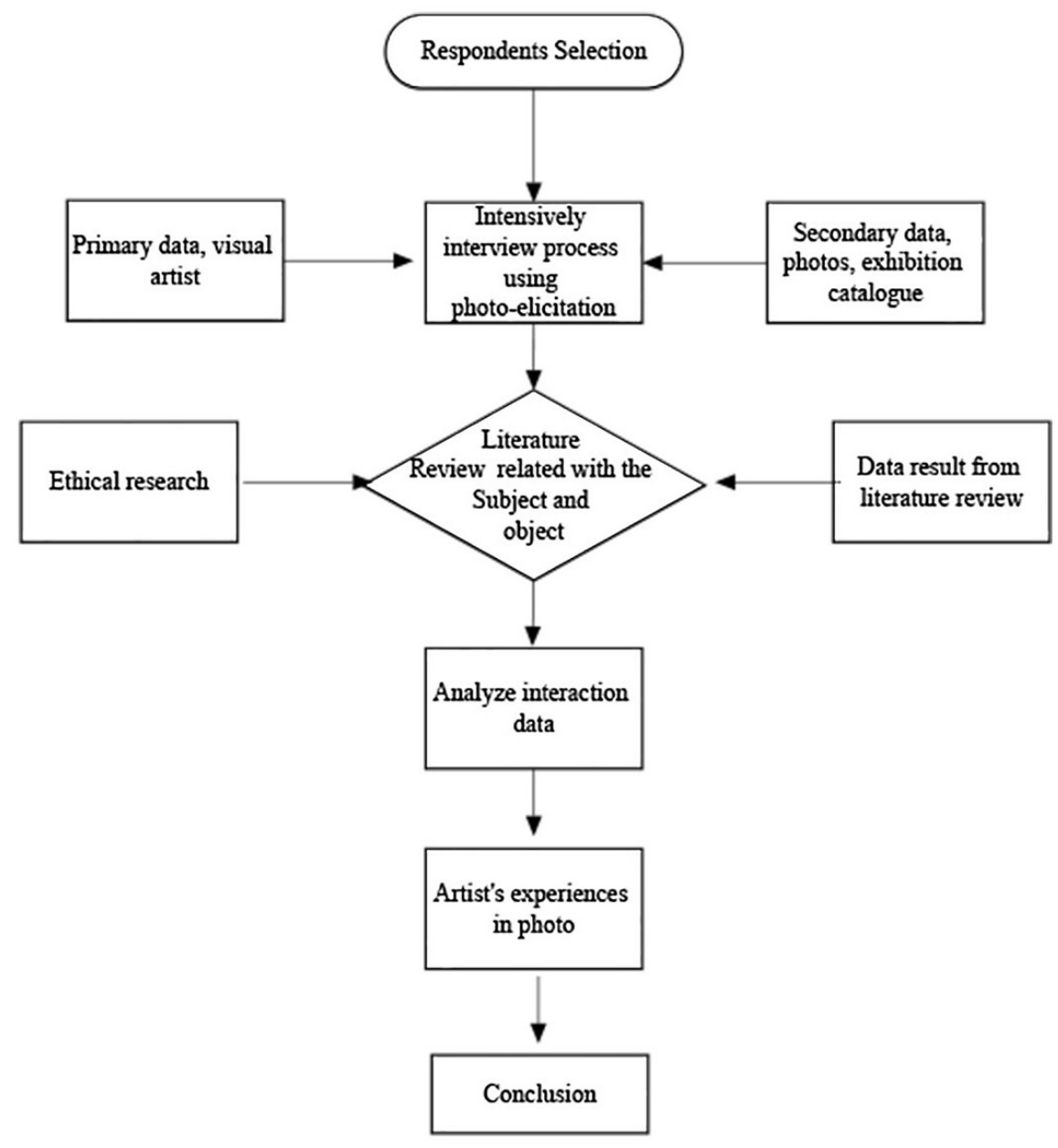

Figure 1. Scheme of research process

3.6 Interview Steps

This study is qualitative descriptive using the diachronic approach which is referred to as photo-elicitation from John Collier. The subject of this research is focusing on serial photos of "Republik Kresek" by Pandji Vasco da Gama. Process of In-depth interview using fishbone diagram: 


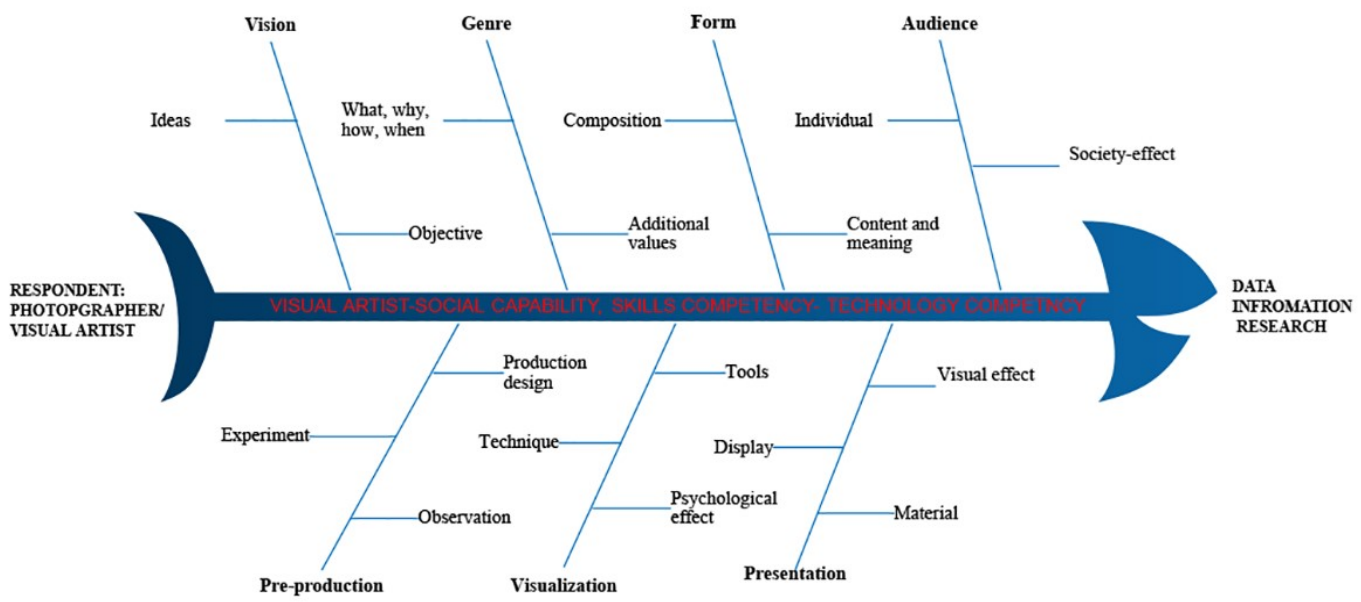

Figure 2. Scheme of photo elicitation interview fishbone diagram. Source: (Prasetyo, 2020).

The "fish" picture in the scheme was interpreted as a meaningful connection within the respondent, such as a visual artist who is capable of social, skills,s and adequate technology resources. In detail, those modalities exposed in the body, such as vision, genre, shape, audience, and all were connected in the creative process, preproduction step, visualization until presentation.

That scheme is assumed as a production machine, that was able to produce a visual product from the beginning until post-production. In another way, it describes the process from finding ideas, revealing the main goal, how to deal with the shape, production system until the impact of the product itself. Photo as the production result becomes data resources from the whole process by the photographer. Data would emerge as shape, form, media, text, and context with meaning. Observation upon Information process starts with presenting the photo to the respondent. Connected with the memory and human senses, respondents will "awake" the photo.

The interview process will be guided as in scheme (Figure 1). It flows from the tail, body with the bones branches which symbolized questions of the interview. Then, it directly goes to head fish that consist of information and data, both in verbal and non-verbal. Photos become space for the respondent to think, to take the action, and speak out of what they see, hear, feel during the creative process. It is in line with the purpose of the photo-elicitation technique, there are: reveals the cultural understanding, psychological aspects, and knowing the suitability between ideas and social action in society during the creative process. In an interview, respondents give responses by analyzing photos and communicating them. As it said in the beginning, it needs to take steps in the interview process.

\section{Research Experience Using Photo-Elicitation}

The following discussion is about the researcher's experiences using the photo-elicitation method. The researcher uses the qualitative questions in order to get data from semi-structured interviews, observation, and artifact utilization. The Photo-elicitation method is chosen because it meets the purposes of methodological study. For example, using photo documents that related to respondents (see figure 3). The benefit of using photo-elicitation methods, such as: reveal and describing respondent's experiences during an interview, becoming an ice-breaker in an interview, gathering respondent's background information, idea, perception, act, and technical of taking pictures, and guiding the goal of discussion toward researcher's goal.

This is the interview transcript between researcher and respondent, Pandji Vasco Da Gama, that focuses on the process of making his serial photo, "Republik Kresek". 


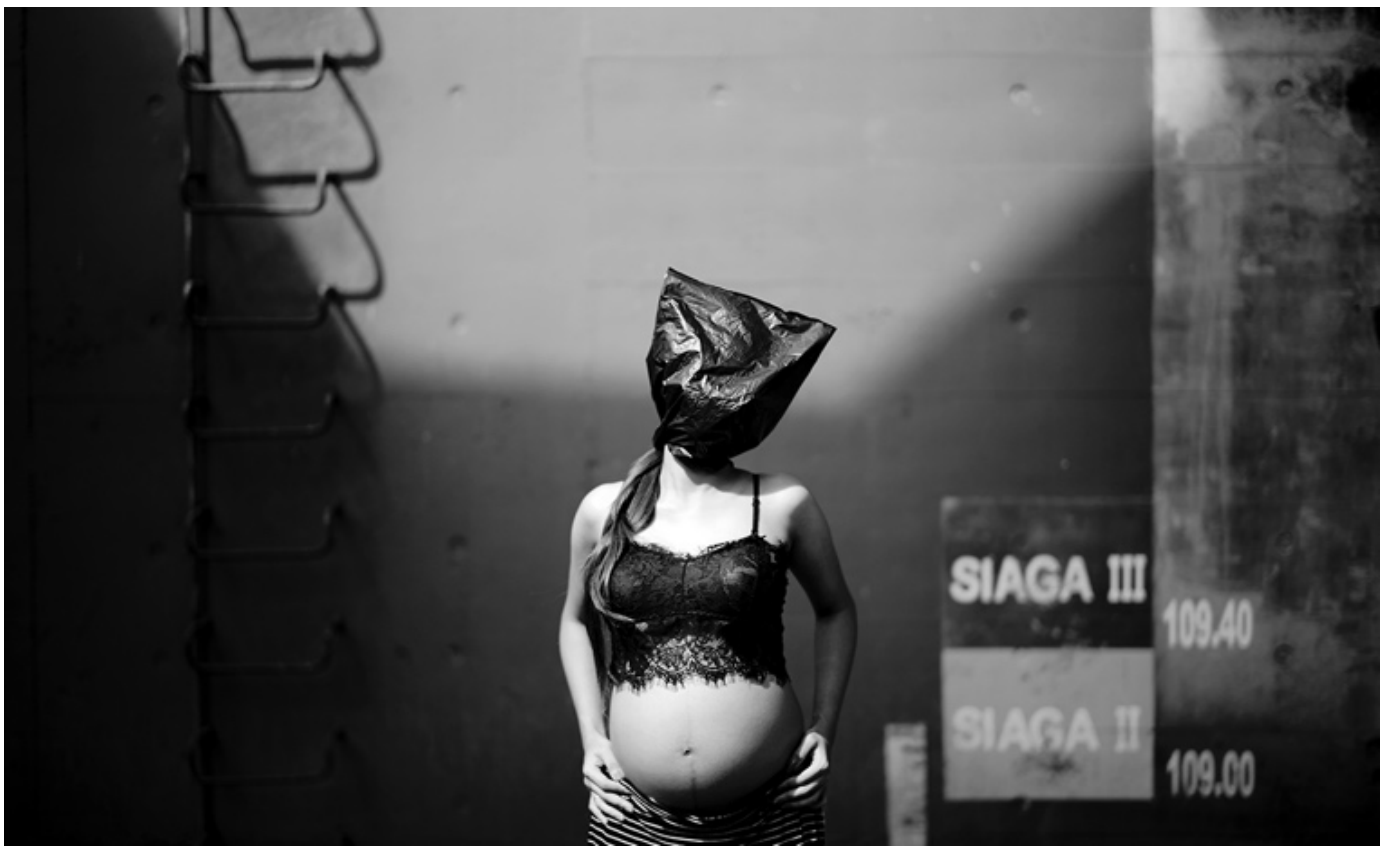

Figure 3. "Stop..stop...can take a breathe ..."

Source: Pandji Vasco Da Gama (2019).

\subsection{About Pre-Production}

Pre-production is the step when observation and preparation are conducted to produce photos. Pandji observes the issue of plastic waste pollution. Pandji was curious about the impact of its. So, he observed through literature, news, television, and the internet to find out about the waste problem.

"...I was doubt about the news, is it real or just hoax. But for sure, I was shocked and tried to ngomong (speak up) about it. So, to be an artist is not only just create something that represent their feeling and opinion, but also representing society's concern. Then, I was thinking, what should I make? As an painting artist and as urban people. The waste problem is also made by urban people. So I decided to make creation related with plastic waste".

Pandji sees that experience is an important thing in life. Since 2012 Pandji started to create networking consist of people with different profession and generation. That process gives him experiences and upgrading his skills as visual artist.

"I saw a seal kenak (trapped) a tier. I saw a dolphin's fin hurt because of a fisherman net. Those animals were hurt by humans. I am a human, so I want to warn and remind people if they ngrasake (felt) what the animals did, with my version". Pandji's observation finally found some interesting issues related with waste problem.

"There were so much data about the waste pollution problem, especially plastic waste. The problems seem saking kulino (common) to talk about and it made people ngenthengke (not aware) of it. Furthermore, plastic is cheap and easy to get, in warung (retail shop), market as goods packaging. At a glance, I remembered a warning written in a plastic bag in a foreign country. It was written like this: 'Keep away from children. I said that is a good way to send messages if plastic can kill and danger for the environment. I should make people can feel the pain when they cannot breathe because covered by plastic. I need to show what will happen in 50 years if we still use plastic. It's not only about the ocean or wildlife conservation, but we already surrounded by plastics waste".

Pandji chooses plastic bags as an object and human beings as the target in order to save the earth from plastic pollution with his way as a dual dimension photographer. Pollution is harmful to the environment.

The pre-production formulation for each photo is different. It depends on their character. In photography, the pre-production process covers observation, experiment, and production design. The observation could be held in line with idea actualization. Each photographer has his own way to visualize their idea in the photo. In some cases, between ideas and the result of visualization does not match. It could be a technical or shape problem. It also happened to Pandji. He felt not comfortable in determining the shape. But, finally, Pandji got insight to choose the firm idea. Through photography principles, he could produce photos that matching with his ideas.

"If we talk about photos, it is related with reality...there was a saying "No pic, hoax". So when we 
see the picture, so we believe it. Even, not all photos are true, but I took that as a challenge for me when making a fiction story with photos. I doubted when selecting visual, but I got my own principle that I hold it tight, "simple, means simple in working on it and in visualization".

Exploration to find the nendang (spectacular) ideas required two months for Pandji. He desired to make photos that grabbed people's attention. Not just only photo documentation about people's activity throwing the garbage or scarping the garbage can. Many people have taken that kind of photo. Sketch skills "triangle head" inspired Pandji to select people's heads with plastic bags.

"At the beginning of exploration, I took a photo of my wife. First in my workspace and stairs, but still did not get better ideas. The photos were too easy to guess that the head was just only put by plastic. So I used the triangle head technique in the sketch to make the plastic looks like people's heads. I make an inverted triangle for the plastic and it directed the view to the body. The first photo was made in the Colo reservoir in Sukoharjo, Central Java. I asked my wife to put off her clothes and just used kolor (pants). Kolor makes my wife wear sayak (Javanese traditional dress for women). With this photo, I felt satisfied and I have to continue it...".

Pandji explains that an accurate photo, (photo 1), is adequate light from a side angle, composition, lines, black and white style, and gesture. It was compound in a simple shape. In the tight-angled space, the model could grab attention from the audience. Simple experiences in responding shaping in orientation and exploration process helped Pandji to choose visualization.

\subsection{Visualization}

Photo is a visual form with fewer words but still contains a lot of meanings. Barthes in Ahmad confirmed that photography is an important phenomenon in point of view science, history, sociology, and aesthetic aspect (Wan Lokman, 2018). In the introduction, Beawiharta, the curator from "Republik Kresek" who has experience as a photojournalist, said: "With the photos, Pandji got the social critical problem as other journalists did. But, Pandji shows it with different way from others".

As a professional curator with experience in making his artificial reality and from the point of view of iconography, Pandji's photos are meaningful and symbolize the waste problem recently. With one photo prototype, Pandji approached the object photo in a persuasive way. The Black and white technique was chosen to accommodate simple and deep concepts. Pandji said, "Colours technique sometimes made people just remember with the colors," he said with drank tubruk coffee. In process of visualization, Pandji counted on natural lighting and a digital Leica camera was taken because of its precision. Camera technology is used to get an approach with the subject photos who were met. Pandji shared the photo with the subject.

About camera technology, Pandji shared his opinion,

"I already struggle with the camera. I felt always got homework, then I got a toll, like it or not, I had to maximize it. What for? I said to myself that I need produce a lot of photos. 'Take it first and the story would come up later. When taking photos, eyes catch the photography aspects and make forget the ideas, it usually happens that war. But I did not, make the ideas first and then take the camera to take the photos".

\subsection{Shape}

Visualization elements in 20 photos of "Republik Kresek" consist of black and white photos, horizontal form, static composition, and plastic "kresek" which is designed with "a triangle head" in order to make a simple shape. Pandji, with his visual conscience, applied those elements. Sullivan said:

"It is the pervading law of all things organic, and inorganic, of all things physical and metaphysical, of all things human and all things superhuman, of all true manifestations of the head, of the heart, of the soul, that the life is recognizable in its expression, that form ever follows function. This is the law" (Sullivan, 2010). 


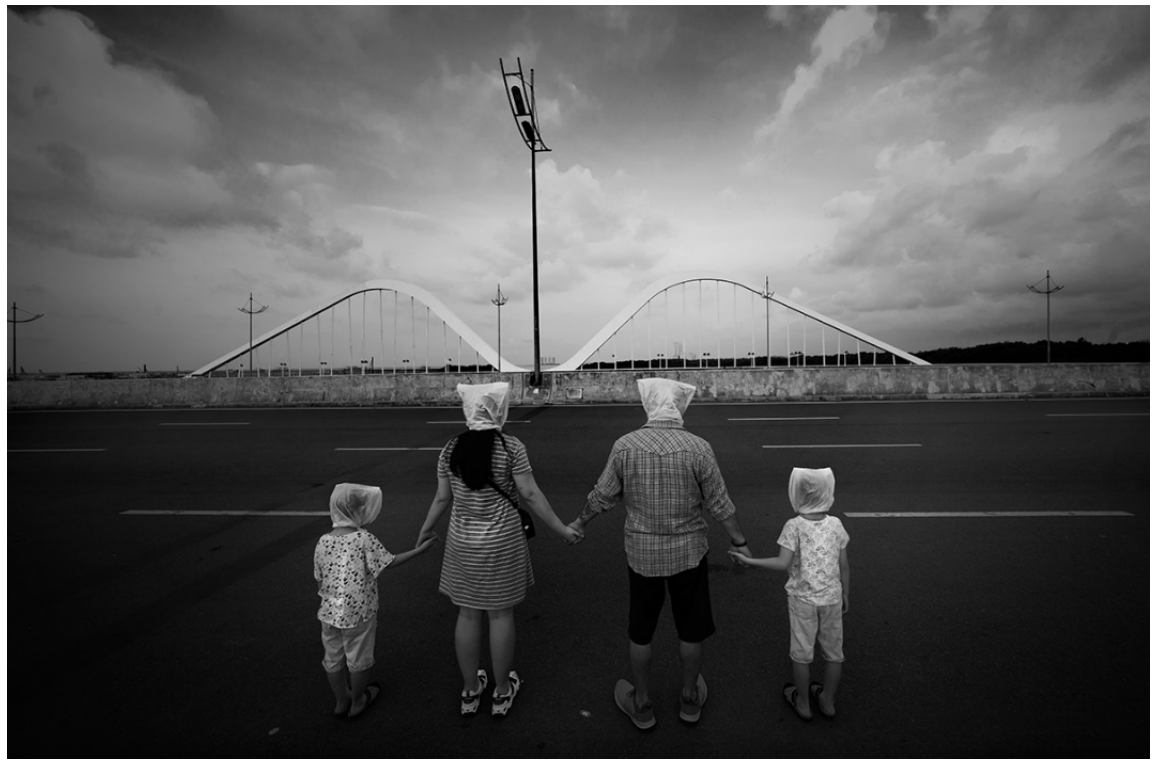

Figure 4. "Dad..., If like this, I can not see anything"

Source: Pandji Vasco Da Gama (2019).

In figure 4 above, the shape is presented not only to help the audience identify a photo but also to guide us to recognize how the natural component could survive or not. The plastic on the head symbolized intimidating (the human and plastic, fishes in plastic, and all human activities). The photo above shows a family who was going to recreation and saw the mountains.

"Imagine that we were asked to see a mountain, but we could not see anything because of plasticcovered our head. We love children, I asked my children to join this photos, I feel it was matched, these photos are all about their fate...".

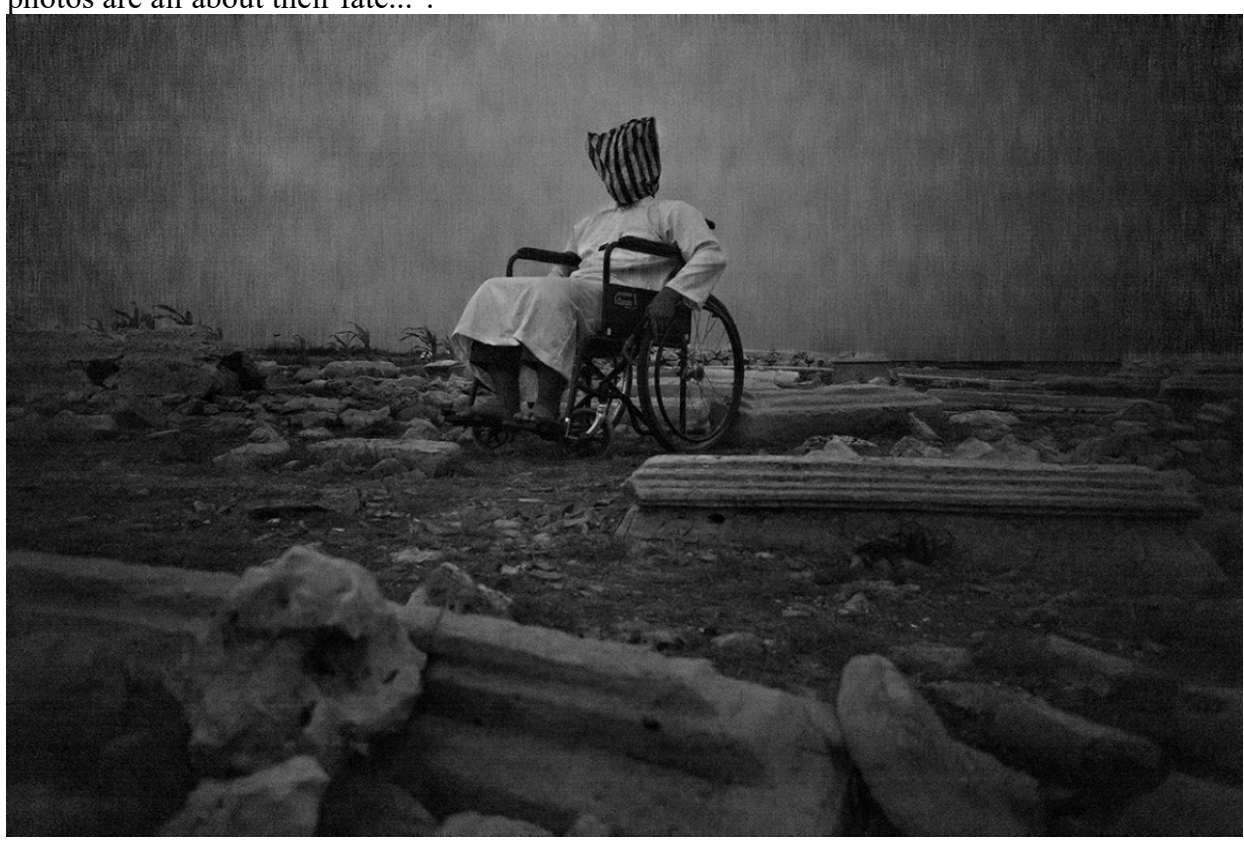

Figure 5. "I Remember of Death and Sins"

Source: Pandji Vasco Da Gama (2019).

\subsection{Exhibition}

Photos were presented with the "models" as a subject through the spontaneous saying in the title. Photos were printed with glossy photo paper on PVC. The size is $50 \mathrm{~cm} \times 70 \mathrm{~cm}$ and framed with acrylic material. Pandji said that every presentation accommodated the photographer's contribution to reaching visual effect. "I chose the material like a mirror, just to make the audience feel like standing in front of the mirror. So, they would feel like 
what the subject felt in the photo".

At the end of the exhibition, Pandji gave a photo with the religious insight with the photo of a man wearing gamis (Moslem outfit for praying) and sitting in a wheelchair. His head was covered with black-white plastic kresek. The man is surrounded by the tombs nuance. In the text, the man said: "I remember death and sins" (Mudji Sutrisno, 2019). Five months project made Pandji wary to be in a dark situation, hardly breathing and sweat made his chins wet, "It is enough, just once I did it, and it was so scary" he said at the end of a conversation.

\section{Conclusion}

The photo-elicitation interview technique takes an important part for the visual researcher in getting information and revealing the meanings of creative aspects of a photographer through a photo. It might not be able to do with conventional interview techniques. Photos are able to stimulate the memory of respondents rather than verbal (Prasetyo, 2020). On the other hand, the photo-elicitation technique gives an opportunity to integrate daily experiences and wider structural social and economic perspectives (Leonard and McKnight, 2015).

In this research, three of 20 photos in "Republik Kresek" were chosen by Pandji. Those photos represented his ideas and message during the interview. Three photos symbolized the process of cultural understanding and enthusiasm from the photographer about the recent phenomenon which he faced every day about plastic waste, then negotiating ideas about its effect and dangers for environment and creating the shape of visualization that responding the phenomenon. After that, formulating narration and held in exhibition space.

The photo-elicitation interview technique is able to use when the researcher could not do observation toward the subject directly. It means that the researcher is unable to find the details from the event because it is already finished or the researcher is not at the place when the event happened. Conducting the methodology in this study, the researcher was helped by the photo-elicitation technique to get data about the "photographer's voice" beyond the photo and also gave navigation for the audience when starring the photo. Meanwhile, from a metaphor point of view, the photo gives data from a psychological aspect, not only just numbers. It is about momentum, feelings, attitude, or previous behavior from the respondent. All of it gathers pure data that is able to research process in order to reveal the empiric cultural understanding.

\section{Acknowledgment}

I would like to thank Pandji Vasco Da Gama for his provide with valuable information through his experiences and photos in writing this article. Likewise, Hangga Wismabrata, who helped translate this paper. This work was supported by the Center for Research and Development of Community Service, Learning Systems, and Quality Assistance Indonesian Institute of Arts Surakarta with grant number: 929/IT6.2/PG/202.

\section{References}

Banks, M. (1998) "Visual anthropology: Image, object and interpretation," Image-based research: A sourcebook for qualitative researchers. Falmer Press. Taylor \& Francis Group., pp. 9-23.

Banks, M. and Zeitlyn, D. (2015) Visual Methods in Social Research. Second Edition. doi: $10.4135 / 9781473921702$

Clark-Ibanez, M. and Stanczak, G. (2007) Visual Research Methods: Image, Society and Representation. Edited by null. (null).

Collier, J. et al. (1986) Visual Anthropology: Photography as a Research Method. University of New Mexico Press. Available at: https://books.google.co.id/books?id=fDn8CrH8gRoC.

Creswell, J. W. (2012) Educational Research: Planning, Conducting, and Evaluating Quantitative and Qualitative Research. Fourth. Edited by P. A. Smith. Boston: Pearson Education, Inc.

Harper, D. (1986) "Meaning and Work: A Study in Photo Elicitation," Current Sociology, 34(3), pp. 24-46. doi: $10.1177 / 001139286034003006$.

Harrist, A. W. (2014) "Combining native instant photography and photo - elicitation," (May). doi: $10.1080 / 08949468.1991 .9966559$.

Leonard, M. and McKnight, M. (2015) "Look and tell: using photo-elicitation methods with teenagers," Children's Geographies. Routledge, 13(6), pp. 629-642. doi: 10.1080/14733285.2014.887812.

Michael Quinn, P. (2002) Nontraditional Regulations, and Innovations in Darning-Centered, Doctoral Education, Including Faculty Meetings That Are Interesting and Important, an Indication of Knovation of the Highest Order, Qualitative Anquiry. Available at: http://books.google.com/books/about/Qualitative_research_and_evaluation_meth.html?id=FjBw2oi8E14C.

Mudji Sutrisno (2019) "Pesan Kenabian di Republik Kresek - Kompas.id." Available at: https://kompas.id/baca/gaya-hidup/2019/10/13/pesan-kenabian-di-republik-kresek/ (Accessed: December 5, 2020).

Olien, M. D. (1968) : "Visual Anthropology: Photography as a Research Method . John Collier, Jr..," American 
Anthropologist, 70(4), pp. 837-837. doi: 10.1525/aa.1968.70.4.02a00880.

Patton, M. Q. (2015) Qualitative research \& evaluation methods: integrating theory and practice LK https://UnivofPretoria.on.worldcat.org/oclc/890080219, Ta - Tt -.

Prasetyo, A. (2019) "Cara Melihat," Acintya Jurnal Penelitian Seni Budaya, 11(1), pp. 16-28. doi: 10.33153/ACY.V11I1.2610.

Prasetyo, A. (2020) ELISITASI FOTO: METODE PENGUMPULAN DATA DALAM PENELITIAN VISUAL. 1st ed. Surakarta: ISI Press.

prosser, J. (2005) Image-based Research: A Sourcebook for Qualitative Researchers. Edited by J. prosser. Philadelphia: Routledge, Falmer, USA Falmer Press, Taylor \& Francis Inc., Philadelphia.

Richard, V. et al. (2014) "Photo-elicitation : reflexivity on method , analysis , and graphic portraits," (November 2016). doi: 10.1080/1743727X.2013.843073.

Richard, V. M. and Lahman, M. K. E. (2015a) "Photo-elicitation: reflexivity on method, analysis, and graphic portraits," International Journal of Research and Method in Education. doi: 10.1080/1743727X.2013.843073.

Richard, V. M. and Lahman, M. K. E. (2015b) "Photo-elicitation: reflexivity on method, analysis, and graphic portraits," International Journal of Research and Method in Education, 38(1), pp. 3-22. doi: 10.1080/1743727X.2013.843073.

Rose, G. (2001) Visual Methodologies An Introduction to the Interpretation of Visual Materials, SAGE Publications Ltd 6 Bonhill Street London EC2A 4PU.

Sarwo, E. F. R. (2016) Teori Wawancara Psikodignostik, PT Leutika Nouvalitera. Leutikaprio. Available at: https://books.google.co.id/books?hl=id\&lr=\&id=uS96DwAAQBAJ\&oi=fnd\&pg=PA1\&dq=teknik+pengum pulan+data+wawancara\&ots=zHXayNBd5b\&sig $=$ Pu8f_NzSHiMSTV2Nhw7ofiDccw8\&redir_esc $=y \# v=o n$ epage \&q=teknik pengumpulan data wawancara\&f=false $\% 0 \mathrm{Ahttps} / / /$ books.google.co.id/boo.

Schwartz, D. (1999) "Objective representation: Photographs as facts," Picturing the past: Media, history and photography, pp. 158-181.

Series, N. and Jun, N. (2015) "Visual Anthropology: Photography as a Research Method by John Collier , Review by : S . Hudson Stable URL : http://www.jstor.org/stable/2798536 .,” 3(2), pp. 328-329.

Suchar, C. S. (1989) "The sociological imagination and documentary still photography: The interrogatory stance," Visual Sociology. doi: 10.1080/14725868908583637.

Sullivan, L. (2010) "Form follows function," De la tour de bureaux artistiquement.

Wan Lokman, I. Z. and A. D. 2018. (2018) "Foto hitam putih masyarakat Melayu abad ke-19 karya Gustav Richard Lambert," Wacana Seni Journal of Arts Discourse, 17, p. : 77-106. doi: https://doi.org/10.21315/ws2018.17.3. 